\title{
Creating Pathways to Literacy Learning; A Comparative Approach Using Hierarchical Linear Modeling (HLM) Analysis
}

\author{
William Kofi Koomson
}

\begin{abstract}
This study used hierarchical linear modeling to compare two literacy programs in the United States. I explored the relationship between community stand alone literacy programs and family literacy programs to ascertain the impact of learner participation and outcome. This study hypothesized that the family literacy program emphasizes active learning through social interaction, which promotes bonding and bridging social capital; and that participating in the family literacy programs enhances learning and learners' achievement in standardized test scores. The study population covered 3,700 adults and 4,000 children who participated in the adult basic education programs in Pennsylvania, U.S. The result provided enough statistical differences in the comparative mean and standard deviations scores between the two literacy programs. Consequently, this led me to reject the null hypothesis in favor of the alternative that students who participated in the Family Literacy programs with high bonding and bridging social capital did have higher achievement scores than Community ABE/GED programs.
\end{abstract}

Index Terms - Adult basic education, persistence in literacy education, social capital, social practices of the classroom.

\section{INTRODUCTION}

The purpose of this study was to compare two literacy program models in the United States. I explored the relationship between community stand alone literacy programs and family literacy programs to ascertain the impact of learner participation and outcome. The purpose of the study was to address questions pertaining to outcomes of learners with basic skills deficiencies. I explored, through literature review, a comparative analysis of learner participation and numerous "barriers" that hinder literacy program participation. This author hypothesized that the family literacy program emphasizes active learning through social interaction, which promotes bonding and bridging social capital; and that participating in the family literacy programs enhances learning and learners' achievement in standardized test scores.

Literacy acquisition is a level playing field for those who have the ability to provide extra tuition for their children, those who can afford to live in affluent communities with favorable zip codes; but the field is skewed against some in society, the poor, those on public assistance, and those who are not able to spend beyond the basic necessitates of life, like, food, shelter, and clothing. Some in our society have

Manuscript received July 19, 2016; revised October 31, 2016.

The author is the Executive Director for the Center for Adult and Distance Education at Valley View University, Ghana (e-mail: wkk109@yahoo.com). continuously fought the injustices of how the public school system, that was supposed to educate their children, do educate them, rather to be among the bottom tier in this modern day technology-rich society. There are many "who lack basic opportunities of health care, or functional education, or gainful employment, or economic and social security" [1]. There are many deprivations of human freedom, "a great many people in different countries of the world are systematically denied political liberty and basic civil rights" (Sen, 2000:15). Literacy acquisition is basic civil rights. Stuart Greene [2] argued that educational reforms based on standardized achievement test scores actually mask racist ideologies that reproduce deficit gaps they claim to address in the first place.

According to the Organization for Economic Cooperation and Development (OECD), knowledge is divided into four general categories. Knowing what - knowledge of facts; knowing why - knowledge of explanations derived from principles for instance, laws or theories; knowing how methodological knowledge associated with the competencies and skills for carrying out a task; and knowing who information method relating to the way knowledge is distributed in its different forms. Despite this worth of "knowing," the OECD [3] reported that 53 percent of the global adult illiterate population live in South and West Asia, 24 percent in sub-Saharan Africa, 12\% in East Asia and the Pacific, and $6.2 \%$ in the Arab States. These statistics are clear indications that the world still subsists in a "knowledge-divide."

The Jomtien [4] World Conference on Education for All (EFA) and the World Education Forum [5] addressed concerns about the inadequate provision of basic education, especially in developing countries. The adoption of EFA reaffirmed the concept of education as a fundamental human right and urged the nations of the world to intensify their efforts to meet the basic learning needs of all children, youth, and adults. In the United States, a Coalition for Education for All (USCEFA) was formed in support of the goals of EFA as a means to bridge domestic and international education agendas [6]. This policy postulates that, "every adult American will be literate and will possess the knowledge and skills necessary to compete in the global economy and exercise the rights and responsibilities of citizenship" (National Education Goals, 1992 p. 3) [7]. Notwithstanding this action plan, the U.S. Department of Education [8] reported that bout 70 percent of prison inmates are illiterate, 19 percent of high school graduates cannot read, and about 14 percent of U.S. adults read below basic levels.

They also found that little has changed between 2003 and 
2013 in adults' ability to read and understand sentences and paragraphs or to understand documents such as job applications. In the United Kingdom, only about 49.2 percent of high school graduates achieved five or more higher grades in GCSE (General Certificate of Secondary Education) in 2000 [9]. The above trend is also true in most developed and developing nations [10]. Non-completion of high school often serves as warning sign of future literacy difficulty. Many of those who are not able to complete high school, or those who drop out of the system, later enroll in adult basic education (ABE) programs. Reasons given ranges from, repeating a grade, didn't like school in general, had disciplinary problems, had a family to support, or had trouble managing both school and work [11], [12]. In ABE programs, however, adult learners are voluntary participants (unless mandated by federal or state regulations), and their roles as students are just one of many roles and responsibilities competing for their time and attention. Reasons such as lack of child-care, transportation, and job demands are often cited as the causes of stop out or withdrawal [13], [14].

\section{The AdUlt Basic EdUCATION Program}

The Division of Adult Education and Literacy (DAEL) advance programs that help adults to get the basic skills they need to be productive workers, family members and citizens. These programs (Adult Basic Education, Adult Secondary Education, English as a Second Language (ESL) Acquisition, and Even Start Family Literacy) emphasize basic skills such as reading, writing, math, English language competency and problem solving. Adult education and literacy programs are funded through federal grants to the states. The Division provides assistance to states to improve program quality and capacity. The federal government has provided funding for many years to assist states in establishing and expanding basic education programs for individuals age 16 and over who have not completed high school. The types of services and providers funded under federal legislation, as well as the program's target population, have changed a number of times since it began [15]. Originally established under the Adult Education Act of 1966, the adult education program is currently governed by the Workforce Innovation and Opportunity Act (WIOA) which was signed into law by President Obama on July 22, 2014. This Act reauthorizes the Adult Education and Family Literacy Act (AEFLA) with several major revisions. WIOA became effective on July 1, 2015, with several provisions, such as the Unified and Combined State Plan and the performance accountability system [16].

The 2003 National Adult Literacy Survey (NALS,) categorized the U.S. population into five different levels of competencies in relation to a test of reading and math abilities, under three scales: prose, document, and quantitative. These categories comprise the literacy tasks that simulate the types of demands that adults encounter in everyday life. Prose literacy tasks include understanding and using information from texts such as editorials, newspaper articles, poems, and stories. Document literacy tasks include locating and using information found in common artifacts such as job applications, bus schedules, maps, payroll forms, indexes, and tables. Quantitative literacy tasks include performing arithmetic operations required as prose and documents encountered in everyday life (e.g., completing a bank deposit slip, writing a checkbook, filling an order forms, and loan applications) [17].

According to the NCES and the National Assessment of Adult Literacy, approximately 43 percent of adults (93 million people) do not have the literacy skills required to fully reach their potential at home, at work and in the community. Fourteen percent of these individuals, or 30 million American adults, are below basic skill level unable to read and understand any written information in English or have great difficult reading. They have few basic skills and are able to do no more than the simplest and most concrete literacy skills such as signing a form or totaling a bank deposit entry. Another 29 percent of the population, or 63 million adults, are at the basic skill level. They can deal only with materials that are simple and clearly laid out. The National Center for Education Statistics (NCES) noted that in our technological society growing numbers of individuals are expected to be able to attend to multiple features of information in lengthy and sometimes complex displays. Thus to compare and contrast information, to integrate information from various parts of a text or document, to generate ideas and information based on what they read, and to apply arithmetic operations sequentially to solve a problem [17].

This study is significant for many reasons. For several decades, the United States Federal government has been involved in literacy education; however, the nature and extent of federal attention to the needs of basic skills learners has varied over these periods. From its earliest days, the government provided funds to establish, encourage, and expand programs to assist learners in overcoming educational deficiencies, which would hinder productive and responsible participation in the life and growth of the nation. At the state level, evening schools for high school drop outs and adults, part-time education, citizenship education, and English language classes for speakers of other languages (or ESOL), and the Chautauqua experience [18] were forerunners of the adult education movement. State histories give evidence of organized adult education as early as the 18th century. However, it was not until the early 1960's, in the Kennedy administration that poverty and adult literacy became a concern. Building on Kennedy's efforts, President Lyndon Johnson and Congress launched a series of programs to end poverty and increase the role of the federal government toward the improvement of education. Since then, there have been continuous programs focused on increasing adult literacy skills. Any study that furthers the understanding of the survivability of these literacy program initiatives described above can only serve to better ensure their continuity.

\section{EFFECTS OF SOCIAL PRACTICES OF THE ClASSROOM AND LITERACY ACQUISITION}

\section{A. Classrooms as Institutional Settings}

Classrooms, as institutional settings, have a social and cultural history that allows them to have both stable and emergent characteristics [19]. Further, classrooms are 
constitutive of multiple activity systems that interact to promote learning. Learning, however, is not always a benign activity; thus, conflict, tension, and contradiction contribute to the idiosyncratic nature of learning activity [20]. Learning also is not an individual process but rather a 'transactional' [21] process mediated by the use of cultural tools such as writing or spoken language as people participate in routine activities in communities of practice such as literacy classrooms [22], [23], [24]. Participation in social-interactional processes promotes individual knowledge production and critical empowerment [25]. Social interaction also requires the teacher to adequately plan to lead the discussion while students get the opportunity to ask questions and contribute to the discussion because they have effectively prepared for participation [26]. Therefore, students and teachers (facilitators), equally engage in a democratic participation to examine different perspectives, allowing the classroom discussion to go beyond the status quo [27].

Central to Paulo Freire's epistemology, literacy is not approached as merely a technical skill to be acquired, rather literacy acquisition provides economic and social empowerment and it is an individuals' civil rights. Most importantly, literacy for Freire is not only a social problem; it is also a political process whereby citizens acquire reading skills, mathematical abilities, and understand the subject matter which leads to transformation. In this sense, "literacy is fundamental to aggressively constructing one's voice as part of a wider project of possibility and empowerment" [28]. The potential for multiple spaces exists in literacy education classrooms. Gutierrez and Stone [22] have argued against the seeming "monologism" of learning space in the classroom. According to them, the teacher is not the only voice to be heard in the classroom - that is, the classroom space should be dialogical. Therefore, moving away from the dominant social practices of school where students respond to the acceptable normative practices.

There is, therefore, the need for a theoretical category of a "discursive space" to identify and describe the competing discourses and epistemologies of the different social actors in the social practice of literacy learning [29]. The discursive space will become the "third space" to transform differences between the learners and facilitators "into rich zones of collaboration and learning." In this way, the discursive space will provide the intermediation platform for future learning development. The significance here is that, there is the need to challenge the exclusive use of more traditional measures of leaning to a more expanded understanding of learning and achievement, especially when applied in the context of literacy learners.

\section{B. Adult Learners and the Learning Process}

Our thinking about adult learners and the learning process are shaped by the knowledge of how adults change and develop across the lifespan [30], and the environment in which learning occurs plays an important role in successful learning [31]. The literature on adult learning and development has expanded during the past decade. However, most of the empirical work in adult education has been based on learning theories developed by educational psychologists. For example, Smith's [32] learning how to learn model;
Knowles' [33] experience-based learning approaches, and Tough's [34] learning projects model, may be traced to psychologically based learning theories [35].

Claims about learning and development are defined by the theories underlying the claims [36]. For example, the radical nativists contend that mental states are determined by genetic make up or are built into the mind/brain. Within such framework there cannot be any development, because the mental structures exist when the infant is born [37] and that the change that occurs throughout life must be defined as "learning." However, the radical behaviorist observes behavior and seeks to determine the conditions that affect a given behavior [38]. To the radical behaviorist, infants are born without knowledge and the environment controls the process of adaptation through the role it plays in establishing and modifying contingencies. Development, then, is only a process of learning [39]. On the other hand, the structuralists view development as a process of creating powerful structures out of weaker structures.

Piaget's [40] theory suggests that cognition has its base in the biological capacities of human infants, and that knowledge is derived from action. He theorized that discrepancies between existing schemes or concepts and contemporary experiences promoted cognitive development. Piaget's cognitive development emphasized a process in which individuals investigate, explore, discover, and rediscover meaning in their world. Learning in this view was simply the application of existing mental structures to new contexts [39]. Vygotsky's [41] sociocultural approach claimed that what is learned on the 'interpersonal' plane is then internalized on the 'intrapersonal' plane and becomes development. In analyzing Vygotsky's work, Davydov [42] inferred that the mental structures and functioning of people raised in a specific culture would be different from those raised in other cultures. He further argued that, individuals could promote their own cognitive development by seeking interactions with others who can help draw them to higher levels of functioning within their "zone of proximal development" [43].

\section{Research Questions}

In this study, the author addressed the following questions concerning outcomes of citizens with basic skill deficiencies who participated in community (stand-alone) adult basic education and Even Start family literacy ABE programs.

\section{1) Questions 1}

1) Do Community ABE/GED and Even Start family literacy programs differ given students' reading scores as measured by TABE, CASAS, and GED?

2) Do Community ABE/GED and Even Start family literacy programs differ given students' mathematics scores as measured by TABE, CASAS, and GED?

\section{2) Questions 2}

1) If programs are different given reading scores, does type of program explain the difference?

2) If programs are different given mathematics scores, does type of program explain the difference?

3) Questions 3

1) Do family literacy adult basic education programs with 
high bonding and bridging social capital also has higher learner achievement than stand-alone Community ABE/GED programs?

2) Does the length of time participating in the family literacy programs with bridging social capital influence adult literacy skills assessment scores?

\section{Theoretical Framework}

Globalization and lifelong learning goals raises the question of what one can realistically expect literacy acquisition learners to achieve. Literacy programs are educational programs and as such, it is reasonable to expect learners to learn, that is, to acquire knowledge, skills, change, and new meaning (human capital), because of their educational participation. However, human capital investment alone without the associated social networks (social capital) may impede learning and economic empowerment.

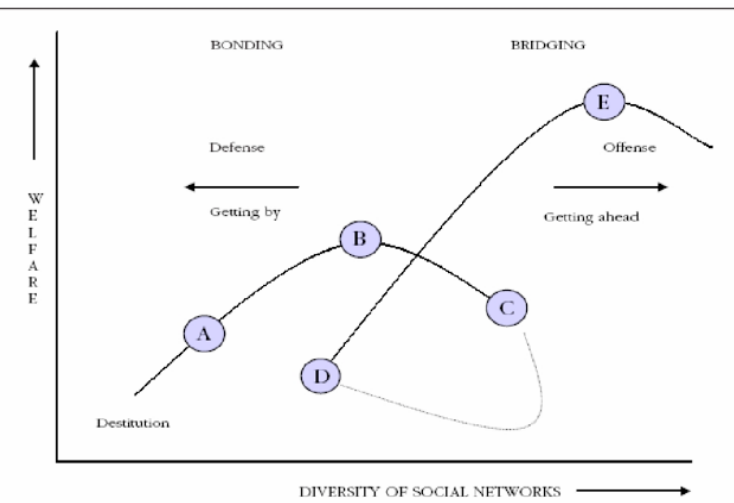

Fig. 1. Social Capital and Poverty Transitions (Source: Woolcock (2000)).

The network view on social capital, therefore, attempts to account for both its upside and its downside. It stresses the importance of vertical as well as horizontal associations between people and of relations within and among such organizational entities as community groups and firms. Strong intra-community ties give families and communities a sense of identity and common purpose [44]. This view also stresses, however, that without weak intercommunity ties, such as those that cross various social divides based on religion, class, ethnicity, gender, and socioeconomic status, strong horizontal ties can become a basis for the pursuit of narrow sectarian interests. The former has been called "bonding" and the latter "bridging" social capital [45]. Different combinations of these dimensions, it is argued, are responsible for the range of outcomes that can be attributed to social capital.

Fig. 1 [46] shows that as the social networks of the poor become more diverse, so too does their welfare. The social capital residing in a given network can be leveraged or used more efficiently, which is essentially the genius of peer group interaction as embedded in the family literacy adult basic education program. The individual adult with minimal basic skills learns literacy and employable skills by participating in family literacy programs. This basic skills acquisition helps the adult to expand her human capital and thereby improve her family's welfare (A). However, the economic returns on mere human capital investments soon reach a limit (B), especially when they rely on high endowments of human capital investment. If the individual adult continues to expand
- for example, through further education - her resources may become overwhelmed, thereby reducing the wellbeing of long-established investment (C). At this level, diminishing returns set in; that is, the individual may be "underemployed" or "unemployed" due to "overqualification." In these circumstances, many individuals partially divest themselves of their immediate community ties (D) and find a potentially more diverse network where "bridging" social capital is more abundant and economic opportunities more promising (E). Migration from villages to cities, belonging to a community, or a religious group is the most dramatic example of this situation.

\section{DATA AND METhodology}

I tested patterns of relationships among potential social capital indicators including the length of time adults participated in the adult basic education programs, and the resulting educational outcome. The study population covered 3,700 adults and 4,000 children who participated in the family literacy programs in Pennsylvania, U.S. During the program year, the Pennsylvania Adult Basic Education program funded more than 180 literacy programs across the State. Services were provided by a range of agencies including libraries, local education agencies, literacy councils, state correctional institutions, community colleges, community-based organizations, faith-based organizations, and universities. About 3,200 adults participated in English language and civics education, 1,900 adults participated in the workplace and workforce education, while 900 adult students participated in distance learning education. This study included sampling of all adult students who enrolled in the adult basic education program for both family literacy model and stand-alone model. The random sampling list included 180 agencies in Pennsylvania that offered about 940 programs throughout the state.

I addressed the issues of persistence, duration, and potential social capital indicators in participating in the adult basic education program as follows:

1) Persistence in participation: Adult learner persistence in this study was a potential "predictor" variable, and was defined as the "time in class based on attendance records" [47], [48].

2) Duration of participation: Duration is an amount of time or a particular time interval. Duration of participation in this study was a potential "predictor" variable. Kassab, Askov, Weirauch, Grinder, \& Van Horn, [49] defined duration in family literacy programs as the "number of days" in the program.

3) Social capital indicators in participation: Social capital indicators in participation was a potential "predictor" variable in this study. Dika and Singh [50] reported that social capital indicators and indicators of educational attainment are positively linked. In this study, social capital was a "binary variable," a qualitative predicator with only two possible values (yes or no). That is " 1, , if individual adult student received "social capital based instruction," and " 0 ," if individual adult student did not receive "social capital based instruction." 
4) Socioeconomic status (SES): Non-Caucasian and native-born adults with low literacy skills who participate in adult basic and literacy education tend to be of low socioeconomic status. The following socio-economic factors influence participation in ABE programs: labor force status, public assistance, household status, entry income, gender, ethnicity, parent-child relationship, and residential factors. Socio-economic status was defined in this study to be a composite measure of social class of low/high income level plus area of student residence (rural/urban) [51], [52].

5) Response variables: The potential "response" variables in this study were tests scores of the TABE, CASAS, and GED subtests (reading skills, total mathematics, and listening skills). St.Pierre, Ricciuti \& Creps [53] prepared a synthesis of the methods and findings from more than 100 local evaluation reports. By far the most popular assessment was the TABE (Tests of Adult Basic Education), which was used by 73 percent of all projects. Although some projects administered the CASAS (Comprehensive Adult Student Assessment System) and others, none of these tests for adults was used by more than one-third of the projects. This study, however, employed the combination of CASAS and TABE post-test scores and GED "actual-test" scores (for reading skills, mathematics skills, and the listening skills) as the dependent variables.

\section{RESUlts}

TABLE I: FREQUENCY DISTRIBUTION* FOR GENDER, ETHNICITY, AND AREA

\begin{tabular}{|c|c|c|}
\hline & \multicolumn{2}{|c|}{ Sample** } \\
\hline & $f$ & Percent \\
\hline \multicolumn{3}{|l|}{ Gender } \\
\hline Female & 4194 & 56.7 \\
\hline Male & 3203 & 43.3 \\
\hline \multicolumn{3}{|l|}{ Ethnicity } \\
\hline White & 3127 & 42.3 \\
\hline Black & 2723 & 36.8 \\
\hline Hispanic & 1080 & 14.6 \\
\hline Asian & 458 & 6.2 \\
\hline Other*** & 9 & 0.1 \\
\hline \multicolumn{3}{|l|}{ Area } \\
\hline$\overline{\text { Rural }}$ & 2544 & 34.4 \\
\hline Urban & 4853 & 65.6 \\
\hline
\end{tabular}

The sample of this study consisted of 7,397 adult basic education students from both Community ABE and Family Literacy programs. Out of the 940 programs, 50.3 percent were $\mathrm{ABE}$ Community and Institution programs and 31.1 percent were GED Community and Institution programs. Nine percent of the total programs were for Even Start and Family Literacy programs, while the remaining 9.6 percent were Literacy Corp, ESL Civic, and PA WIN (Pennsylvania Workforce Improvement Network) programs. Table I summarizes the demographic data of this sample. Fifty-seven percent of the students from the sample were female and 43 percent were male. Ethnic backgrounds of the students were

composed of 42.3 percent Caucasian, 36.8 percent African American, and 14.6 percent Hispanic.

\section{A. Descriptive Statistics for Main Study Variables}

Six percent of the students were Asians and one percent comprised of other ethnicity, which is made up of Native Americans and Pacific Islanders. Majority of PA-ABE program students were urban dwellers (65.6 percent) and 34.4 percent of the students resided in rural areas. Table II presents minimum, maximum, means, and standard deviations for the main study variables for 7397 students.

TABLE II: DESCRIPTIVE STATISTICS

\begin{tabular}{lrrrr}
\hline & Min & Max & Mean & Std. Dev \\
\hline Instructional Hours & 80 & 1128 & 146.246 & 86.454 \\
Standardized Test Scores & 200 & 710 & 449.729 & 135.671 \\
CASAS Test Scores* & 153 & 262 & 216.419 & 18.702 \\
GED Actual Test* & 76 & 726 & 438.512 & 126.204 \\
TABE Test Scores* & 160 & 812 & 532.766 & 75.514 \\
Reading Skills** & 200 & 710 & 453.866 & 134.838 \\
Total Mathematics** & 200 & 665 & 489.967 & 97.945 \\
Listening Skills** & 200 & 238 & 215.269 & 8.687 \\
Program Size & 1 & 249 & 127.499 & 79.809 \\
Household Status*** & 179 & 185 & 180.080 & 1.317 \\
\hline
\end{tabular}

* $\mathrm{CASAS}=1861 ; \mathrm{GED}=488 ; \mathrm{TABE}=5006$

$* *$ reading scores $=4676$; total math $=2252$; listening skills $=469$

*** Household Status (Code)

Head of Single Parent Household

Head of Spouse/Partner in 2 Parent

Head of Spouse/Partner-no dependents

Dependent member of Househol

Living in Group Quarters

Living Alone

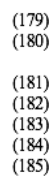

The average hours of instruction in adult education that students participated in ABE programs were 146 hours $(\mathrm{M}=$ 146.25 , s.d. $=86.45)$. Majority of the students reported that they were head or spouse/partner in two-parent household (M $=180$, s.d. $=1.32$ ), and students had completed about nine to 10 years of schooling at the time of entry into the ABE program. The average scores on standardized test were: CASAS $216(\mathrm{M}=216.42$, s.d. $=18.70)$; GED Actual Test $439(\mathrm{M}=438.51$, s.d. $=126.20)$; and TABE test scores were $533(\mathrm{M}=532.77$, s.d. $=75.51)$. Overall, students' performance according to this study is acceptable within the National Reporting System (NRS) [54] benchmarks. According to NRS, students performing at these levels are able to read simple descriptions and narratives on familiar subjects or from which new vocabulary can be determined by context. They can also make some minimal inferences about familiar texts and compare and contrast information from such texts but not consistently.

\section{B. Unit of Analysis (Using Hierarchical Linear Modeling)}

Substantial differences existed among adult basic and literacy programs [55]. Programs focused on seven categories of outcomes endorsed by state directors: economic impact, credentials, learning gains, family impact, further education and training, community impact, and customer satisfaction [55]. Most adult basic education programs are developed as school-based programs, with the school (program) being the unit assigned to experimental conditions and the students (learners) within the program, receiving the intervention. The data structure, therefore, is hierarchical with the learners (level-1 or micro-level) nested within programs (level-2 or macro-level). A multilevel analytical approach that takes 
interdependence into account in the analytical process integrates the features of the lower (individual level) and higher (program level) order levels of analysis. The specification of appropriate within- and between-program error structures for a simultaneous estimation of all effects allowed a more precise, and perhaps optimal, estimation of effects at both individual and school levels [51], [56].

Hierarchical linear model analyses were done to address three general research purposes. These were; improved estimation of effects within individual units; formulation and testing of hypotheses about cross-level effects (varying program size affected the relationship between social class and academic achievement within programs [52]; and the partitioning of variation among sets of student-level variables into within- and between-program components.

\section{Multilevel Analyses}

The original sample for the level-1 unit was made up of: Community $\mathrm{ABE}=6069 ;$ Family Literacy $=1,328$. The level-2 unit sample was 249 programs from a total of 940 programs. To accurately analyze the research questions using HLM, further data editing was done to eliminate programs that had fewer than five (5) students. Also listening skills scores were deleted from the HLM file due to insufficient cases to do the modeling. Many programs had fewer than five students; however, a value of five students per program was selected as a minimum for running the HLM. Reading scores and mathematics scores were the two main measures and they were analyzed independently in two HLM analyses. For the reading scores, the student sample size was 4525 , the program sample size was 121 , and at least 5 students were enrolled in each program. The smallest program had 5 students while the largest program had 600 students.

\section{Hypothesis Testing}

Hypothesis - 1: Differences Between Programs

1) Community $\mathrm{ABE} / \mathrm{GED}$ and Even Start family literacy programs do not differ significantly given students' reading scores as measured by TABE, CASAS, and GED.

2) Community $\mathrm{ABE} / \mathrm{GED}$ and Even Start family literacy programs do not differ significantly given students mathematics scores as measured by TABE, CASAS, and GED.

To analyze hypothesis one (1a and 1b), a "One-Way ANOVA with Random Effects" was used. The simplest possible hierarchical linear model is equivalent to a one-way ANOVA with random effects. The one-way ANOVA with random effects provided useful preliminary information about how much variation in the outcome lied within and between programs and about the reliability of each program's sample mean as an estimate of its true population mean. As shown in Tables III and IV, the means by program were significantly different for reading, $\mathrm{F}(120,4403)=44.98, \mathrm{p}<.0001$; and for mathematics $\mathrm{F}(68,2055)=16.56, \mathrm{p}<.0001$.

Estimating the one-way ANOVA model was useful as a preliminary step in a hierarchical data analysis. It produced a point estimate and confidence interval for the grand mean. It also provided information about the outcome variability at each of the two levels [52]. The variance parameter represented the within-group variability and the tau- 00 ( $\tau 00$ is the population variance among the program means) captured the between-group variability (see Tables III and IV).

TABLE III: RESULTS FROM THE ONE-WAY ANOVA MODEL READING SCORES FOR ALL PROGRAMS

\begin{tabular}{|l|l|l|l|l|l|} 
& Sum of Squares & df & $\begin{array}{l}\text { Mean } \\
\text { Squares }\end{array}$ & F & Sig. \\
\hline BetweenGroups & 45138216.369 & 120 & 376151.80 & 44.97 & .000 \\
Within Groups & 36824212.819 & 440 & 3 & 6 & \\
Total & 81962429.187 & 3 & 8363.437 & & \\
& & 452 & & & \\
\hline
\end{tabular}

TABLE IV: RESULTS FROM THE ONE-WAY ANOVA MODEL MATHEMATICS SCORES FOR ALL PROGRAMS

\begin{tabular}{|l|l|l|l|l|l|}
\hline & Sum of Squares & df & $\begin{array}{l}\text { Mean } \\
\text { Squares }\end{array}$ & F & Sig. \\
\hline Between Groups & 7156657.015 & 68 & 105244.95 & 16.563 & .000 \\
Within Groups & 13057797.065 & 2055 & 6 & & \\
Total & 20214454.080 & 2123 & 6354.159 & & \\
\hline
\end{tabular}

Table $\mathrm{V}$ presents the results from the random-coefficient model (Covariance Parameter Estimates).

TABLE V: COVARIANCE PARAMETER ESTIMATES (SAS) HLM ANALYSIS

\begin{tabular}{|c|c|c|c|}
\hline Subset & Estimate & Standard Error & Z Value \\
\hline Reading Skills & 8957.19 & 1227.94 & $7.29 * *$ \\
\hline Mathematics Skills & 3512.74 & 671.34 & $5.23^{* *}$ \\
\hline
\end{tabular}

** $\operatorname{Pr} \mathrm{Z}<.0001$

The results for the programs differed randomly given reading and mathematics skills scores. The results were similar to those previously reported for the one-way ANOVA model. Programs differed randomly given reading and mathematics skills scores. The Random Coefficient for reading skills scores, $\tau 00=8957.19, Z=7.29, \mathrm{p}<.0001$; and mathematics skills scores, $\tau 00=3512.74, Z=5.23, p<.0001$ were significant, therefore, I concluded that programs were different.

Hypothesis - 2: Comparison of Community ABE and Family Literacy Programs

1) Type of program does not explain the variance; programs vary randomly given reading scores.

2) Type of program does not explain the variance; programs vary randomly given mathematics scores.

To answer these research questions, an HLM "Intraclass Correlation Coefficient" a Covariance Parameter Estimates, using SAS and SPSS Test of Between-Subject Effects (ANOVA table), were computed. The intraclass correlation coefficient measured the proportion of variance in the outcome that was between groups (thus: the level-2 units). It was estimated by substituting the variance components for their respective parameters. The intraclass correlation coefficient (see Table V) for Reading Skills was $(8957.19) /(8957.19+8364.35)=.517$. This meant that approximately 52 percent of the variance in students' reading scores was attributed to the programs in which they were enrolled. The intraclass correlation coefficient for Mathematics Skills was $(3512.74) /(3512.74+6352.19)=$ 
$3512.74 / 9864.93=35.61$. This meant that approximately 36 percent of the variance in students' mathematics scores was attributed to the programs in which they were enrolled. The question then became, did type of program $(0=$ Community ABE/GED; 1 = Family Literacy) explains the difference?

A further analysis of means and standard deviation for mathematics and reading scores as a function of community $\mathrm{ABE} / \mathrm{GED}$ and family literacy programs revealed that programs differed, again at the student-level, based on average mathematics and reading scores (see Table VI). Therefore, type of program did influence students' reading and mathematics scores. The HLM and SPSS analyses indicated that adults who were enrolled in the family literacy programs performed better in both reading and mathematics skills scores than those students enrolled in the community $\mathrm{ABE} / \mathrm{GED}$ program for the same period.

TABLE VI: MEANS, STANDARd DEVIATION, AND N FOR MATHEMATICS AND READING SCORES AS A FUNCTION OF COMMUNITY ABE/GED AND FAMILY LITERACY PROGRAMS

- $\quad$ Community ABE/GED Family Literacy Total

$\begin{array}{llllllllll}\text { Subtest } & \mathrm{n} & \mathrm{M} & \mathrm{SD} & \mathrm{n} & \mathrm{M} & \mathrm{SD} & \mathrm{M} & \mathrm{SD}\end{array}$ Mathematic Skills $1571487.97 \quad 100.52553 \quad 498.33 \quad 88.33 \quad 490.6797 .58$ Reading Skills $\quad 3793448.26138 .43731489 .05106 .50454 .85134 .62$ Total $\quad 5364936.23238 .951,284987.38194 .83945 .52232 .20$

To triangulate the hierarchical linear modeling (HLM) results above, hypothesis 3(a) (b) analyzed the data when all the predictors and the response variables, including the subtest (reading skills, mathematics skills, and listening skills) with total sample of 7397 were considered using ANOVA and correlation statistics.

Hypothesis - 3: Comparison of Community ABE and Family Literacy Programs

1) Family Literacy programs with high bonding and bridging social capital do not have higher learner achievement scores than community ABE/GED programs

2) The length of time participating in the family literacy programs with high bonding and bridging social capital does not influence adult literacy achievement scores.

The emphasis for hypothesis 3(a) (b) was learning achievement at the student-level; an Independent Sample $t$ Test statistics was used. An Independent Sample t Test is employed when investigating the difference between two unrelated or independent groups (in this case, Community $\mathrm{ABE}$ and Family Literacy Programs). The analysis provided two statistical tests. The F test was not significant for listening skills (.84); this meant that the assumption was not violated, and the "Equal variance assumed" line was used for the $t$ test and related statistics. However, the Levene's F was statistically significant at alpha .05 level for reading skills and total mathematics; thus, the variances were significantly different and the assumption of equal variances was violated. Therefore, the "Equal variance not assumed" line was used. The $\mathrm{t}$ in scores on listening skills was not statistically significant $(\mathrm{p}=.075)$. However, the results for reading and math scores were statistically significant (reading, $\mathrm{t}=-9.38$, degree of freedom $(\mathrm{df})=1262.39$, and $\mathrm{p}=.001$; scores on math, $\mathrm{t}=-2.38$, df $=1099.85$, and $\mathrm{p}=.017$ ). I therefore concluded that, there were differences between community $\mathrm{ABE}$ programs and family literacy programs.

\begin{tabular}{|c|c|c|c|c|c|c|}
\hline Variable & $\mathrm{N}$ & M & $\mathrm{SD}$ & $t$ & df & $p$ \\
\hline Reading Skills & & & & -9.380 & 1262.393 & .000 \\
\hline Community $\mathrm{ABE}$ & 3937 & 447.219 & 138.585 & & & \\
\hline Family Literacy & 739 & 489.274 & 106.072 & & & \\
\hline Total Mathematics & & & & -2.383 & 1099.850 & .017 \\
\hline Community $\mathrm{ABE}$ & 1683 & 487.282 & 100.740 & & & \\
\hline Family Literacy & 569 & 497.910 & 88.774 & & & \\
\hline Listening Skills & & & & -1.783 & 467 & .075 \\
\hline Community $\mathrm{ABE}$ & 449 & 215.118 & 8.680 & & & \\
\hline Family Literacy & 20 & 218.650 & 8.364 & & & \\
\hline
\end{tabular}

The above table indicated that the family literacy programs were significantly different from community ABE programs on reading skills $(\mathrm{p}=001)$ and total mathematics $(\mathrm{p}=017)$. Inspections of the two group means indicated that the average reading skills score for community ABE programs (447.22) was significantly lower than the score (489.27) for family literacy programs. A similar trend existed for total mathematics. The mean score for community ABE programs (487.28) was lower than the score (497.91) for family literacy programs. However, community ABE programs did not differ significantly from family literacy programs on listening skills $(\mathrm{p}=.075)$.

Since the assumption of equal variances was violated, I ran the appropriate nonparametric statistic, which in this case was the Mann-Whitney (M-W) U test. The M-W was used with a between group design with two levels of an independent variable. The Mann-Whitney test (Table 8) is a nonparametric test to compare two unpaired groups. This test is an alternative to the independent group t-test, when the assumption of normality or equality of variance is not met.

TABLE VIII: NON PARAMETRIC TEST: MANN WHITNEY U

\begin{tabular}{|c|r|r|r|r|}
\hline \multicolumn{5}{|c|}{ RANKS ON TABE, CASAS, \& GED } \\
\hline & Program & N & \multicolumn{1}{l|}{ Mean } & \multicolumn{1}{l|}{ Sum of } \\
& & & Rank & Rank \\
\hline scores on reading Community ABE & 3937 & 2287.31 & 9005140.00 \\
& Family Literacy & 739 & 2611.21 & 1929686.00 \\
Total & 4676 & & \\
scores on math Community ABE & 1683 & 1116.01 & 1878237.50 \\
& Family Literacy & 569 & 1157.54 & 658640.50 \\
Total & 2252 & & \\
scores on listening Community & 449 & 232.64 & 104453.50 \\
ABE & 20 & 288.08 & 5761.50 \\
& Family Literacy & 469 & & \\
Total & & & \\
\hline
\end{tabular}

The above table showed the mean or average ranks for community $\mathrm{ABE}$ and family literacy programs on each of the three dependent variables. SPSS ranked the students from 4,676 (highest) to 1 (lowest) for "reading skills," 2,252 (highest) to 1 (lowest) for "total mathematics," and 469 (highest) to 1 (lowest) for "listening skills," so that, in contrast 
to the typical ranking procedure, a high mean rank indicated the group scored higher. On all three subtests (reading skills, total mathematics, and listening skills) family literacy students ranked higher than Community ABE/GED students. Table IX confirmed the results of the Mann-Whitney (M-W) $\mathrm{U}$ test and the previous HLM analysis.

TABLE IX: COMPARATIVE MEAN AND STANDARD DEVIATIONS OF COMMUNITY ABE AND FAMILY LITERACY PROGRAMS VARIABLES

\begin{tabular}{|c|c|c|c|c|c|c|}
\hline & \multicolumn{3}{|c|}{ Community $\mathrm{ABE}$} & \multicolumn{3}{|c|}{ Family Literacy } \\
\hline & $\mathrm{N}$ & Mean & s.d & $\mathrm{N}$ & Mean & s.d. \\
\hline Test Scores & 6069 & 441.16 & 140.25 & 1328 & 488.90 & 103.76 \\
\hline Instruction Hours & 6069 & 144.45 & 86.89 & 1328 & 154.47 & 83.95 \\
\hline Reading Scores & 3937 & 447.22 & 138.58 & 739 & 489.27 & 106.07 \\
\hline Math Scores & 1683 & 487.28 & 100.74 & 569 & 497.91 & 88.77 \\
\hline Listening Scores & 449 & 215.12 & 8.68 & 20 & 218.65 & 8.36 \\
\hline
\end{tabular}

As evident in Table IX and above analyses, there were enough statistical differences in the comparative mean and standard deviations scores between the two groups. Consequently, this led me to reject the null hypothesis in favor of the alternative that students who participated in the family literacy programs with high bonding and bridging social capital do have higher achievement scores than community ABE/GED programs.

\section{CONCLUSION}

The statistical analyses at the student-level indicated that adults who participated in the family literacy program performed better in both reading and mathematics skills scores than those students who enrolled in the Community $\mathrm{ABE} / \mathrm{GED}$ program for the same period. Hypotheses tested in this study affirmed the major research questions and the theoretical frame that family literacy programs with high bonding and bridging social capital also have higher achievement test scores than Community ABE/GED programs. Though further research is needed to confirm this finding, this study may contribute to further understanding of what is entailed in creating bonding and bridging social capital in adult basic and literacy education.

In addition, this study postulated that the quality of the social processes and the relationships within which learning take place are especially influential on the quality of learning outcomes. This is consistent with learning that takes place in family literacy programs. However, this causal relationship between quality of social process and learning outcomes may be limited to specific context: family literacy programs that emphasize collaborative learning approach. Therefore, future research could investigate further the real causal relationship between the quality of social process and the quality of learning outcomes by collecting data over time and/or using in-depth interviews.

Educational attainment and grades results in this study were positively associated with strong help networks of parents, number of friends known by parents, and parents' involvement in school. The level of social structures surrounding the family literacy programs promotes strong bonding and bridging social network such as the collaboration of family and child education programs with other community agencies and programs, including social services, health services, and employment services. Finally, this study indicated that though differences existed between the programs, both programs made similar progress towards social capital acquisition.

Longstanding traditional family systems, such as dependence on the extended family and the community, are changing. At the same time, government support is quickly eroding. With all these factors working against the adult learner, one question is, how can adult basic and literacy education programs offer a promising alternative to ensure continuous participation of learners? The results from this research study revealed the need for further research into how both stand-alone Community ABE/GED and Even Start Family Literacy programs may work to attract potential adult learners with multiple forms of literacy needs.

\section{REFERENCES}

[1] A. Sen, Development as Freedom (2nd ed.), New York: Oxford University Press, 2001.

[2] S. Green, Literacy as a Civil Right: Reclaiming Social Justice in Literacy Teaching and Learning, Peter Lang Publishing, New York, 2009.

[3] Organization for Economic Cooperation and Development (OECD, 2000), Knowledge and Skills for Life, First Results from PISA 2000, Paris: OECD, 2001c

[4] Jomtien, "World declaration on education for all: Meeting basic learning needs," presented at the World Conference on Education for All, Jomtien, Thailand, March 1990

[5] Dakar Framework for Action, The World Education Forum: Education for All: Meeting Our Collective Commitments, pp. 26-28, April 2000.

[6] E. B. Fiske and B. O'Grady, "Academy for educational development (U.S.) (AED) education for all: A global commitment: A report of the United States to the International Consultative Forum on Education for All," Washington D.C.: Academy for Educational Development, p. $112,2000$.

[7] National Education Goals Panel, "The national education goals report: Building a nation of learners," Washington, DC: Author, 1992.

[8] United States Department of Education. (Dec. 2015), National Institute of Literacy. [Online]. Available: http://www.statisticbrain.com/number-of-american-adults-who-cant-r ead/

[9] Department for Education and Employment (DfEE), "Schools building on success: Raising standards, promoting diversity, achieving results," Crown Copyright 2001.

[10] UNICEF. (July 2016). Statistics: Ghana education indicators. [Online]. Available: http://www.unicef.org/infobycountry/ghana_statistics.html

[11] J. S. Chall and V. A. Jacobs, "Writing and reading in the elementary grades: Developmental trends among low-SES children," Language Arts, vol. 60, no. 5, pp. 617-626, 1983.

[12] S. A. Walmsley and R. L. Allington, "Redefining and reforming instructional support programs for at-risk students," No Quick Fix: Rethinking Literacy Programs in America's Elementary Schools, pp. 19-44, New York: Teachers College Press, 1995.

[13] B. A. Quigley, "Action research for professional development and policy formation in literacy education," PAACE Journal of Lifelong Learning, vol. 4, pp. 61-69, 1995.

[14] H. Beder, Adult Literacy: Issues for Policy and Practice, Malabar, FL: Krieger, 1991

[15] B. Lasater and B. Elliott, "Profiles of the adult education target population: Information from the 2000 Census," Office of Vocational and Adult Education (OVAE): U.S. Department of Education, Research Triangle Institute (RTI), Washington, DC, April 2004.

[16] United States Department of Education. (July 2016). Office of Career, Technical, and Adult Education: Workforce Innovation and Opportunity Act. [Online]. Available: http://www2.ed.gov/about/offices/list/ovae/pi/AdultEd/wioa-reauthori zation.html 
[17] National Center for Education Statistics (NCES), "National household education survey," Washington, DC: U.S. Department of Education, 2016.

[18] V. Case and R. O. Case, We Called It Culture: The Story of Chautauqua, 1948.

[19] K. Gutiérrez, "How talk, context, and script shape contexts for learning to write: A cross case comparison of journal sharing," Linguistics and education, vol. 5 no. 3-4, pp. 335- 365, 1993.

[20] K. Gutiérrez, B. Rymes, and J. Larson, "Sript, counterscript, and underlife in the classroom: James Brown versus Brown v. Board of Education," Harvard Educational Review, vol. 65, no. 3, pp. 445-471, 1995.

[21] J. Dewey and A. F. Bentley, Knowing and the Known, Boston: Beacon, 1949.

[22] K. Gutiérrez, and L. Stone, "A cultural-historical view of learning and learning disabilities: Participating in a community of learners," Learning Disabilities: Research and Practice, vol. 12, no. 2, pp. 123-131, 2000

[23] J. Lave and E. Wenger, Situated Learning. Legitimate Peripheral Participation, Cambridge: University of Cambridge Press, 1991.

[24] C. B. Cazden, Classroom Discourse: The Language of Teaching and Learning, Portsmouth, NH: Heinemann, 1988.

[25] P. Freire, Pedagogy of the Oppressed, Hagerstown, MN: Harper and Row, 1973.

[26] D. Hess, "Discussion in social studies: Is it worth the trouble?" Social Studies Today: Research and Practice, pp. 205-213, New York, NY: Routledge, 2010.

[27] D. M. Donahue, "The nature of teaching and learning dilemmas: Democracy in the making," Democratic Dilemmas of Teaching Service-Learning: Curricular Strategies for Success, p. 1725, Sterling, VA: Stylus, 2011.

[28] P. Freire and D. Macedo, Literacy: Reading the Word and the World, South, 1987.

[29] K. Gutiérrez, P. Baquedano-Lopez, and M. G. Turner, "Putting language back into language arts: When the radical middle meets the third space," Language Arts, vol. 74 no. 5, pp. 368-378. 1997.

[30] M. C. Clark and R. S. Caffarella, "An update on adult development theory: New ways of thinking about the life course," New Direction for Adult and Continuing Education, no 84, San Francisco: Jossey-Bass, 1999.

[31] S. B. Merriam and R. G. Brockett, The Profession and Practice of Adult Education: An Introduction, San Francisco: Jossey-Bass, 1997.

[32] R. M. Smith, Learning How to Learn: Applied Learning Theory for Adults, Chicago: Follett, 1982.

[33] M. S. Knowles, The Modern Practice of Adult Education, New York: Adult Education, 1980.

[34] A. Tough, The Adult's Learning Projects: A Fresh Approach to Theory and Practice in Adult Learning, University Associates (Learning Concepts), San Diego, and Ontario Institute for Studies in Education, Toronto, Ontario, 1979.

[35] M. C. Smith and T. Pourchot, Adult Learning and Development: Perspectives from Educational Psychology, Mahwah, NJ: Lawrence Erlbaum, 1998.

[36] S. Strauss, "Learning and development (special issue)," Educational Psychologist, vol. 28 no. 3, 1993.

[37] L. Kaye, "Are most of our concepts innate?" Synthese, vol. 95, pp. 187-217, 1993

[38] B. F. Skinner, "The behavior of organisms: An experimental analysis," 1938.

[39] N. Granott, "We learn, therefore we develop: Learning versus development-or developing learning," Adult Learning and Development: Perspectives from Education Psychology, pp. 15-34, Mahwah, NJ: Lawrence Erlbaum Associates, 1998.
[40] J. Piaget, The Equilibration of Cognitive Structures: The Central Problem of Intellectual Development, Chicago: University of Chicago Press, 1977, 1985.

[41] L. Vygotsky, Mind in Society: The Development of Higher Psychological Processes, Cambridge, MA: Harvard University Press, 1978.

[42] V. Davydov, "The influence of L.S. Vygotsky on education theory, research and practice," Educational Researcher, vol. 24, pp. 12-21, 1995.

[43] B. M. Newman and P. R. Newman, Development through Life: A Psychosocial Approach, Wadsworth Publishing Company, 2012.

[44] N .M. Astone, C. Nathanson, R. Schoen, and Y. Kim, "Family demography, social theory, and investment in social capital," Population and Development Review, vol. 25, pp. 1-31, 1999.

[45] R. Gittell and A. Vidal, Community Organizing: Building Social Capital as a Development Strategy, Thousand Oaks, CA: Sage Publications, 1998.

[46] M. Woolcock and D. Narayan, "Social capital: Implications for development theory, research, and policy," The World Bank Observer, vol. 15 no. 2 pp. 225-49, 2000.

[47] B. A. Quigley, Rethinking Literacy Education: The Critical Need for Practice-Based Change, San Francisco: Jossey-Bass, 1997.

[48] J. P. Comings, A. Parrella, and L. Soricone, "Persistence among adult basic education students in pre-GED classes," 1999.

[49] C. Kassab, E. N. Askov, D. Weirauch, E. L. Grinder, and B. V. Horn, "Adult participation related to outcomes in family literacy programs," Family Literacy Forum, vol. 3, no. 1, pp. 23-29, 2004.

[50] S. L. Dika and K. Singh, "Applications of social capital in educational literature: A critical synthesis," Review of Educational Research, vol 72, no. 1, pp. 31-60, 2002.

[51] A. S. Bryk and S. W. Raudenbush, Hierarchical Linear Models. Applications and Data Analysis Methods, Newbury Park, CA: Sage, 1992.

[52] S. W. Raudenbush and A. S. Bryk, Hierarchical Linear Models. Applications and Data Analysis Methods, Thousand Oaks, CA: Sage, 2002.

[53] R. S. Pierre, A. Ricutti, F. Tao, C. Creps, J. Swartz, W. Lee, and A Parsad, The Third National Even Start Evaluation: Program Impact and Implications for Improvement, Cambridge, MA: Abt Associates, 2003.

[54] National Reporting System. (July 2016). Adult basic and literacy education. [Online]. Available: http://www.nrsweb.org/about/

[55] L. Condelli and M. Kutner, Developing a National Outcome Reporting System for the Adult Education Program, Pelavin Associates, Inc.: Washington, D.C. 1997.

[56] H. Goldstein, Multilevel Statistical Models, Edward Arnold (Halstead and J. Wiley), 1995

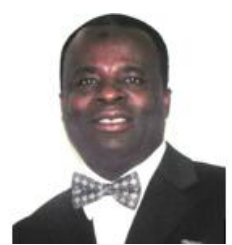

William Kofi Koomson is an associate professor and executive director for the Center for Adult and Distance Education at Valley View University in Ghana. Prior to his current position, he was executive director for the Review and Herald Publishing Association for the Atlantic Union Region of HHES USA. He has a dual-titled $\mathrm{PhD}$ degree from the Pennsylvania State University, USA and double Masters degrees; MBA and MEd from the Cleveland State University, USA. He completed his bachelors' degree majoring in business administration and labor relations. He is a U.S. citizen and was born in Ghana, West Africa. He is married and has four children. 